\title{
Photodynamic therapy against onychomycosis
}

\section{Terapia fotodynamiczna w grzybicy paznokci}

\author{
Juliana P. Lyon', Leonardo M. Moreira² \\ 'Department of Natural Sciences, Federal University of Sao Joao del Rei, Sao Joao Del Rei, MG, Brazil \\ 2Department of Zootechnics, Federal University of Sao Joao Del Rei, Sao joao Del Rei, MG, Brazil
}

'Departamento de Ciências Naturais, Universidade Federal de São Joao del Rei, São João Del Rei, MG, Brazil

2Departamento de Zootecnia, Universidade Federal de São João Del Rei, São João Del Rei, MG, Brazil

Dermatol Rev/Przegl Dermatol 2020, 107, 521-533

DOI: https://doi.org//0.5 | |4/dr.2020. 103888

\author{
CORRESPONDING AUTHOR/ \\ ADRES DO KORESPONDENCJI: \\ Juliana P. Lyon \\ Departamento de Ciências \\ Naturais \\ Universidade Federal de São \\ Joao del Rei \\ Praça Dom Helvécio, 74 \\ Fábricas São João Del Rei \\ MG, Brazil \\ Phone: 5532988436806 \\ E-mail: julianalyon@ufsj.edu.br
}

\begin{abstract}
Photodynamic therapy (PDT) has been considered a suitable alternative for the treatment of onychomycosis, especially for patients who cannot receive oral antifungal agents or with recurrent infections of the nail. This manuscript intends to analyse the published articles that report the use of PDT in vivo for the treatment of onychomycosis. A PubMed search was conducted with the key words photodynamic therapy and onychomycosis, according to the PRISMA guidelines. Only in vivo studies with clinical and laboratorial evaluations were included in the present study. Fourteen manuscripts were evaluated, according to the inclusion criteria defined, comprising a ten years' period of studies. The manuscripts differed widely regarding the number of patients involved, photosensitizer employed, protocol details, time of follow up and outcomes. Different parameters should be compared in order to define the best therapeutic approach and to contribute to a more widespread use of PDT in onychomycosis.
\end{abstract}

\section{STRESZCZENIE}

Terapia fotodynamiczna (photodynamic therapy - PDT) jest uznaną alternatywną metodą leczenia grzybicy paznokci, zwłaszcza u pacjentów, którzy nie mogą przyjmować doustnych preparatów przeciwgrzybiczych oraz z nawracającymi zakażeniami paznokci. W pracy dokonano przeglądu opublikowanych artykułów opisujących zastosowanie PDT in vivo $\mathrm{w}$ leczeniu grzybicy paznokci. Przeszukano bazę danych PubMed, wybierając słowa kluczowe zgodnie z wytycznymi PRISMA: terapia fotodynamiczna i grzybica paznokci. W przeglądzie uwzględniono wyłącznie badania in vivo z oceną parametrów klinicznych i laboratoryjnych. Stosując przyjęte kryteria włączenia, wyłoniono 14 prac obejmujących 10-letni okres badań. Prace różniły się znacząco pod względem liczby analizowanych pacjentów, zastosowanej substancji fotouczulającej, protokołu, okresu obserwacji i wyników. W pracy dokonano analizy porównawczej, aby określić optymalne podejście terapeutyczne i ułatwić szersze stosowanie PDT jako uzupełniającej metody w grzybicy paznokci.

Key words: photodynamic therapy, onychomycosis, PDT, in vivo PDT, photosensitizers, dermatophytosis.

Słowa kluczowe: terapia fotodynamiczna, grzybica paznokci, PDT, PDT in vivo, substancje fotouczulające, dermatofitoza. 


\section{INTRODUCTION}

Photodynamic therapy (PDT) consists in a therapeutic technique widely employed against cancer and infectious diseases. The therapeutic procedure is based on the use of a photosensitizer and light of a specific wavelength in order to generate oxidative stress followed by cellular death [1]. Indeed, although it has been initially developed to treat cancerous cells, it has been successfully employed against several microorganisms [2]. Several authors have demonstrated the applicability of PDT against fungi [3-6].

The mechanism of antimicrobial PDT is the generation of reactive oxygen species that react with microbial targets, leading to cell death. According Calzavara-Pinton et al. [7], the absorption of the photosensitizer by fungal cells is impaired by the cell wall, which is absent in mammals. Initially, the photosensitizer is located in the cell wall and cell membrane. After the perforation of these structures by the PDT-induced reactive oxygen species, the photosensitizer reaches the inner organelles and kill the cell by the same mechanism.

The fungal infection of the nails affects as many as $10 \%$ of the general population varying in different parts of the world [8]. This disease is caused mainly by dermatophytes ( $85 \%)$, however, other fungi such as Candida spp. and Aspergillus may be involved [8,9]

Onychomycosis is very challenging in the clinical practice. The treatment often requires long periods of compliance and the antifungal agents may be expensive or cause toxicity, especially in such longterm therapies. The recurrence rates of the traditional treatments are high and the clinical success rates are moderate to low [10]. In this context, PDT appears as an alternative to the conventional antifungal agents. Although antifungal PDT has been explored in several studies, a relatively small number of articles have presented in vivo application of this treatment.

\section{OBJECTIVE}

Considering the necessity of a broader view on its real applicability, the aim of the present work is to evaluate the efficacy of PDT in vivo for the treatment of onychomycosis.

\section{METHODS}

For the present work, we have employed the Preferred Reporting Items for Systematic Reviews and Meta-Analyses (PRISMA) guidelines [11]. The following criteria were employed in the selection of the manuscripts evaluated: original articles published in the indexed journal which used PDT for the treatment of onychomycosis in humans were considered

\section{WPROWADZENIE}

Terapia fotodynamiczna (photodynamic therapy PDT) jest często wykorzystywana w leczeniu nowotworów i chorób zakaźnych. Procedura terapeutyczna polega na zastosowaniu substancji fotouczulającej i światła o określonej długości fali w celu wywołania stresu oksydacyjnego prowadzącego do śmierci komórkowej [1]. Pomimo że metoda została pierwotnie opracowana w celu niszczenia komórek nowotworowych, może być wykorzystywana również do eliminowania komórek mikroorganizmów [2]. W kilku badaniach wykazano przydatność PDT w leczeniu przeciwgrzybiczym [3-6].

W terapii przeciwdrobnoustrojowej metoda PDT polega na wytwarzaniu reaktywnych form tlenu, które oddziałują toksycznie na mikroorganizmy docelowe, powodując śmierć komórek. W pracy Calzavara-Pinton i wsp. [7] wykazano, że wchłanianie substancji fotouczulającej przez komórki grzybów jest obniżone na skutek obecności ścian komórkowych, które nie występują u ssaków. Początkowo substancja fotouczulająca oddziałuje na ścianę i błonę komórkową. Po przerwaniu ciągłości tych struktur przez reaktywne formy tlenu indukowane podczas PDT fotouczulacz dociera do wewnętrznych organelli komórkowych i powoduje śmierć komórki w tym samym mechanizmie.

Grzybica paznokci dotyczy aż 10\% ogólnej populacji świata, przy pewnym zróżnicowaniu w zależności od regionu [8]. Choroba jest wywoływana głównie przez dermatofity $(85 \%)$, ale potencjalnie także inne grzyby, m.in. Candida spp. i gatunki z rodzaju Aspergillus [8, 9].

Grzybica paznokci stanowi duże wyzwanie w praktyce klinicznej. Leczenie często wymaga długiego okresu przestrzegania zaleceń lekarskich, a leki przeciwgrzybicze mogą być drogie albo powodować objawy niepożądane, zwłaszcza podczas długotrwałej terapii. Wskaźniki nawrotów w przypadku tradycyjnych metod leczenia są wysokie, a wskaźniki skuteczności klinicznej umiarkowane lub niskie [10]. W tym kontekście PDT wydaje się wartościową alternatywą dla tradycyjnych leków przeciwgrzybiczych. Wykorzystanie PDT w leczeniu przeciwgrzybiczym analizowano w kilku badaniach, jednak w stosunkowo nielicznych pracach oceniano stosowanie tej metody in vivo.

\section{CEL PRACY}

Ze względu na konieczność bardziej kompleksowej oceny faktycznej przydatności terapeutycznej PDT poniższa praca ma na celu analizę skuteczności tej metody in vivo w leczeniu grzybicy paznokci.

\section{METODY}

W pracy zastosowano metodologię zgodną z zaleceniami zawartymi $\mathrm{w}$ deklaracji dotyczącej prawi- 
for inclusion. Only studies with histopathological and microbiological initial diagnosis and clear measurement of the outcomes (i.e. microbiological and/or histopathological evaluation following treatment, or well-established clinical improvement of the nail aspect) were considered for inclusion.

PubMed (US National Library of Health Database - August 2019) was accessed for the identification of articles that corresponded to the above inclusion criteria. The following combination of key words was employed in order to standardize the search: onychomycosis and Photodynamic Therapy. No date limits were set. All these procedures were repeated to avoid the exclusion of suitable papers and to improve the reliability of the search. The selected articles were then fully read by the authors.

\section{RESULTS}

The search for the key words onychomycosis and Photodynamic Therapy in PubMed resulted in 67 articles. From these, fourteen met the criteria to be analysed in the present manuscript. Thirteen articles were excluded for being in vitro or animal studies. Thirty-four of them were excluded for being review articles and seven articles were out of the subject. The manuscripts that met our criteria were published between 2008 and 2019, comprising a ten-year period of studies.

One of the first studies about PDT against onychomycosis in humans was published by Watanabe et al. [12]. This study describes two patients who were treated with 5-aminolevulinic acid (ALA) followed by irradiation with pulsed laser light at a wavelength of $630 \mathrm{~nm}$ at $100 \mathrm{~J} / \mathrm{cm}^{2}$. The first patient was previously treated with topical terbinafine with no success and could not receive oral antifungals because of her advanced age. The second patient interrupted oral itraconazole therapy due to gastric pain. The treatment was performed once a week 7 times in patient 1 and 6 times in patient 2 . Both patients reported pain during the irradiation, which disappeared within a day. However, the mycological cure was achieved in both cases with a follow up period of six months for patient 1 and three months for patient 2 .

In the same year, Piraccini et al. [13] published a case report of a 78-year-old woman with total onychomycosis of the toenail. Prior to the PDT, 20\% urea was applied to the toenail and the hyperkeratosis of the nail bed was removed. ALA was applied, followed by irradiation with broadband red light at a wavelength of $630 \mathrm{~nm}$ at $37 \mathrm{~J} / \mathrm{cm}^{2}$ for 7 minutes and 24 seconds at a distance of 5 to $8 \mathrm{~cm}$. The treatment was repeated every 15 days three times. The patient did not report any discomfort during the procedure. dłowego raportowania przeglądów systematycznych i metaanaliz (PRISMA) [11]. Przy selekcji artykułów do analizy zastosowano następujące kryteria: dopuszczano oryginalne prace opublikowane w indeksowanych czasopismach opisujące stosowanie PDT w leczeniu grzybicy paznokci u ludzi; uwzględniano wyłącznie badania z wstępnym rozpoznaniem histopatologicznym i mikrobiologicznym oraz precyzyjnie zdefiniowaną oceną wyników leczenia (tj. badanie mikrobiologiczne i/lub histopatologiczne po zastosowaniu leczenia lub jednoznacznie potwierdzona poprawa kliniczna stanu paznokci).

W celu zidentyfikowania prac spełniających kryteria włączenia do przeglądu przeszukano bazę danych PubMed (należącą do United States National Library of Medicine - sierpień 2019 r.). W celu ujednolicenia wyszukiwania zastosowano następującą kombinację słów kluczowych: grzybica paznokci i terapia fotodynamiczna. Nie ustalono granic czasowych dla publikacji. Wszystkie procedury powtórzono, aby uniknąć wykluczenia z przeglądu prac o odpowiedniej tematyce i zwiększyć wiarygodność wyszukiwania. Następnie wybrane artykuły zostały w całości przeczytane przez autorów niniejszej pracy przeglądowej.

\section{WYNIKI}

Przeszukanie bazy PubMed przy użyciu słów kluczowych grzybica paznokci i terapia fotodynamiczna ujawniło łącznie 67 prac. $Z$ tej liczby 14 prac spełniło kryteria przyjęte na potrzeby przeglądu. Odrzucono 13 artykułów poświęconych badaniom in vitro lub badaniom prowadzonym na zwierzętach. Ponadto wykluczono 34 prace przeglądowe oraz 7 prac, których problematyka odbiegała od tematu przeglądu. Prace wybrane zgodnie $\mathrm{z}$ przyjętymi kryteriami zostały opublikowane w latach 2008-2019 i obejmowały 10-letni okres badań.

Jedno z pierwszych badań analizujących zastosowanie PDT w leczeniu grzybicy paznokci u ludzi opublikowali Watanabe i wsp. [12]. Autorzy opisują przypadki dwóch pacjentek, u których wdrożono leczenie kwasem 5-aminolewulinowym (ALA) oraz naświetlania laserem pulsacyjnym o długości fali $630 \mathrm{~nm}$ $\mathrm{w}$ dawce $100 \mathrm{~J} / \mathrm{cm}^{2}$. U pierwszej pacjentki stosowano wcześniej miejscowe leczenie terbinafiną, jednak bez powodzenia. Ze względu na podeszły wiek niemożliwe było leczenie doustnymi środkami przeciwgrzybiczymi. Druga pacjentka przerwała doustną terapię itrakonazolem z powodu bólu brzucha. Zabiegi wykonywano raz w tygodniu: 7-krotnie $\mathrm{u}$ pierwszej i 6-krotnie u drugiej pacjentki. Obie kobiety zgłaszały ból podczas naświetlań, który ustępował w czasie doby. Obserwacja trwała odpowiednio 6 miesięcy i 3 miesiące. W obu przypadkach terapia 
The clinical and mycological cure was achieved and persisted for 24 months of follow up.

Sotiriou et al. [14] conducted a study involving thirty patients with onychomycosis of the toenail caused by Trichophyton rubrum. The patients had concomitant conditions that prevented the treatment with oral antifungal agents. The nail plate of the patients received an occlusive curative with urea $20 \%$ for ten consecutive nights, so the nail could be removed with forceps. After that, 20\% ALA was applied for 3 hours followed by irradiation with red light (570-670 nm) from a non-coherent light source at a light dose of $40 \mathrm{~J} / \mathrm{cm}^{2}$ and a fluence rate of $40 \mathrm{~mW} / \mathrm{cm}^{2}$. The treatment was repeated three times at intervals of two weeks. All of the patients reported burning sensation of the treated toe and the light treatment had to be interrupted for a few minutes in some patients. After one year, $43 \%$ of the patients were cured by clinical and laboratorial criteria. After 18 months, the percentage dropped to $36.6 \%$.

Aspiroz et al. [15] presents a case report of onychomycosis caused by Acremonium sclerotigenum in the fingernail of a 75-year-old woman which was successfully treated with methyl aminolevulinate (MAL) PDT. The patient was previously treated with conventional oral antifungal agents with no success. The authors utilized MAL at a concentration of $16 \%$ and $630 \pm 10 \mathrm{~nm}$ Light Emitting Diode (LED). The treatment was repeated every 15 days three times. The fungal culture was negative after the third session and the follow up period lasted one year with clinical and mycological cure.

Gilaberte et al. [16] describes two cases of refractory onychomycosis treated with MAL-PDT. The cases involved fingernails affected by non-dermatophyte fungi. In both cases, the nail bed was softened with urea $40 \%$ ointment. MAL (16\%) was applied in the infected areas and then the fingernails were irradiated with $636 \mathrm{~nm}$ LED $\left(37 \mathrm{~J} / \mathrm{cm}^{2}\right)$. The procedure was repeated two more times with a two weeks' interval. The patients were cured according to standard criteria after 6 months.

Another study involving PDT was conducted by Silva et al. [17]. These authors treated a 59 years old man who claimed to have onychomycosis lesions for 30 years. The treatment with Fluconazole was ineffective. Urea $20 \%$ was applied for 10 minutes and $0.5 \mathrm{~mm}$ of the nails thick was removed with a drill. After that, the patient was treated with hematoporphyrin derivative (Photogem ${ }^{\circledR}, 5 \mathrm{mg} / \mathrm{ml}$ ) for one hour and irradiated by LED $\left(54 \mathrm{~J} / \mathrm{cm}^{2}, 630 \mathrm{~nm}\right.$, with an intensity of $100 \mathrm{~mW} / \mathrm{cm}^{2}$ ). The patient reported no pain and the protocol was repeated weekly for six weeks. After the treatment, the microbial culture was negative.

Souza et al. [18] treated four patients with endonyx onychomycosis of the toenail with Methylene zakończyła się wyleczeniem potwierdzonym wynikami badania mykologicznego.

W tym samym roku Piraccini i wsp. [13] opublikowali opis przypadku 78-letniej kobiety z nasiloną grzybicą w obrębie paznokcia stopy. Przed zabiegiem PDT na paznokieć aplikowano mocznik $20 \%$ oraz usuwano hiperkeratozę z łożyska paznokcia. Następnie nakładano ALA i przeprowadzano naświetlanie szerokopasmowym światłem czerwonym o długości fali $630 \mathrm{~nm}$ w dawce $37 \mathrm{~J} / \mathrm{cm}^{2}$ przez 7 minut i 24 sekundy, z odległości 5-8 cm od naświetlanego obszaru. Zabiegi wykonano 3-krotnie, co 15 dni. Pacjentka nie zgłaszała dyskomfortu podczas zabiegu. Pozytywny efekt, który utrzymywał się przez okres obserwacji (24 miesiące), potwierdziły wyniki badania klinicznego i mykologicznego.

Sotiriou i wsp. [14] przeprowadzili badanie z udziałem 30 pacjentów z grzybicą paznokci stóp wywołaną przez Trichophyton rubrum. U pacjentów występowały schorzenia współistniejące, które uniemożliwiały leczenie doustnymi lekami przeciwgrzybiczymi. Na płytkę paznokcia przez 10 kolejnych nocy nakładano pod opatrunkiem okluzyjnym środek o zawartości mocznika 20\%, tak aby można było łatwo usunąć płytkę kleszczykami. Następnie aplikowano 20\% ALA na 3 godziny oraz wykonywano naświetlanie światłem czerwonym (570-670 nm) przy zastosowaniu źródła niekoherentnego światła, w dawce $40 \mathrm{~J} / \mathrm{cm}^{2}$, przy wskaźni$\mathrm{ku}$ fluencji $40 \mathrm{~mW} / \mathrm{cm}^{2}$. Zabieg powtarzano 3-krotnie w odstępach 2-tygodniowych. Wszyscy pacjenci zgłaszali uczucie pieczenia w obrębie poddawanego naświetlaniom palca, a u niektórych osób konieczne było przerwanie naświetlania na kilka minut. Po roku wyleczenie potwierdzone wynikami badań klinicznych i laboratoryjnych odnotowano u $43 \%$ pacjentów. Po upływie 18 miesięcy odsetek ten zmniejszył się do $36,6 \%$.

Aspiroz i wsp. [15] opisali przypadek grzybicy paznokcia ręki wywołanej przez grzyb z gatunku Acremonium sclerotigenum u 75-letniej kobiety, u której zastosowano PDT z aminolewulinianem metylu (methyl aminolevulinate - MAL), uzyskując dobry efekt terapeutyczny. Pacjentka była wcześniej leczona tradycyjnymi doustnymi środkami przeciwgrzybiczymi, jednak bez powodzenia. Autorzy zastosowali MAL w stężeniu $16 \%$ oraz fototerapię światłem LED o długości fali $630 \pm 10 \mathrm{~nm}$. Zabieg powtórzono 3-krotnie, co 15 dni. Po ostatnim zabiegu wynik posiewu mykologicznego był ujemny. Po rocznym okresie obserwacji wyleczenie potwierdzono wynikami badania klinicznego i mykologicznego.

Gilaberte i wsp. [16] opisali dwa przypadki opornej grzybicy paznokci u rąk leczonej metodą MAL-PDT. Schorzenie zostało wywołane przez grzyby niedermatofitowe. W obu przypadkach łożysko 
Blue PDT. The mycological exam showed endonyx onychomycosis caused by T. rubrum in these patients. Endonyx onychomycosis consists in a diffuse milky-white discoloration of the affected nail, with normal thickness of the nail plate, normal surface and absence of hyperkeratosis or onycholysis of the nail bed. This type of onychomycosis is frequently associated with Trichophyton soudanense and Trichophyton violaceum. However, these authors selected four patients with mycological identification of T. rubrum. The authors employed $2 \%$ methylene blue solution followed by irradiation with LED $\left(630 \mathrm{~nm}, 36 \mathrm{~J} / \mathrm{cm}^{2}\right)$, light intensity output of $3100 \mathrm{~mW} / \mathrm{cm}^{2}$ and optical intensity of $100 \mathrm{~mW} / \mathrm{cm}^{2}$ ). The protocol was repeated for 6 months every 15 days. Some lesions needed abrasion with a rotation $3 \mathrm{~mm}$ diamond tip. All of the patients reached mycological and laboratorial cure. No follow up period was specified in this manuscript.

The same authors [19] conducted a comparative study dividing eight onychomycosis patients in two groups. One group was treated with methylene Blue PDT (MB 2\%; LED $630 \mathrm{~nm}, 18 \mathrm{~J} / \mathrm{cm}^{2}$ ) and placebo and the other group received fluconazole in addition to PDT. The follow up was at 3, 6 and 12 months after the therapy. In both groups, $80 \%$ of the patients reached clinical and laboratorial cure after 12 months.

Souza et al. [20] also employed methylene blue PDT to treat 22 patients with onychomycosis caused by T. rubrum. First, an aqueous solution of methylene blue $(2 \%)$ was applied to the affected nails. Sometimes dermo abrasion was necessary. Then, the areas were irradiated with LED $\left(600 \mathrm{~nm}, 100 \mathrm{mV} / \mathrm{cm}^{2}\right)$. The treatment lasted 6 months and was repeated every 15 days. After that all of the patients showed clinical improvement and mycological cure.

Tardivo et al. [21] reported a small trial of photodynamic treatment of onychomycosis using a $1: 1$ mixture of methylene blue $(2 \%)$ and toluidine blue $(2 \%)$ as photosensitizers. The nail was scraped with a sharp curette and this mixture was set between the nail plate and the nail bed for 5 minutes. Subsequent$l y$, the affected area was irradiated with a LED source (600 to $700 \mathrm{~nm}, 100 \mathrm{~mW} / \mathrm{cm}^{2}$ ). Sixty-two patients were tested following this protocol. From those, $45 \%$ reached total clinical cure and $40 \%$ reached partial clinical cure 30 days after the PDT.

Associations have also been tested as new therapeutic schemes for the treatment of onychomycosis. Oliveira et al. [22] tested the association between $\mathrm{CO}_{2}$ fractional laser 10,600 nm laser and PDT with MAL $16 \%$ in the same session. Two sessions of PDT were performed in each patient with an interval of 60 days. The mycological and clinical cure was achieved by all of the seven patients after one year of follow up. Fractional laser removes the area affected by the fungal infection. paznokcia zmiękczano maścią mocznikową $40 \%$. Na miejsca objęte zakażeniem aplikowano MAL $(16 \%)$, a następnie poddawano je fototerapii LED o długości fali $636 \mathrm{~nm}\left(37 \mathrm{~J} / \mathrm{cm}^{2}\right)$. Zabieg powtórzono 2-krotnie w odstępie 2 tygodni. Po upływie 6 miesięcy u pacjentów stwierdzono wyleczenie według standardowych kryteriów.

Inne badanie analizujące PDT przeprowadzili Silva i wsp. [17]. Autorzy leczyli 59-letniego mężczyznę ze zmianami grzybiczymi w obrębie paznokci, które według relacji pacjenta utrzymywały się od 30 lat. Leczenie flukonazolem było nieskuteczne. Zastosowano mocznik 20\% (aplikowany na 10 minut) oraz za pomocą frezu zredukowano grubość paznokcia o 0,5 mm. Następnie na zajęte grzybicą obszary nakładano na godzinę pochodną hematoporfiryny (Photogem $^{\circledR}, 5 \mathrm{mg} / \mathrm{ml}$ ) i przeprowadzano naświetlanie lampą LED $\left(54 \mathrm{~J} / \mathrm{cm}^{2}, 630 \mathrm{~nm}\right.$, natężenie $\left.100 \mathrm{~mW} / \mathrm{cm}^{2}\right)$. Pacjent nie zgłaszał dolegliwości bólowych. Protokół powtarzano co tydzień przez 6 tygodni. Po zakończeniu leczenia uzyskano ujemny wynik posiewu mikrobiologicznego.

Souza i wsp. [18] opisali leczenie 4 pacjentów z wewnątrzpłytkową grzybicą paznokci u stóp z zastosowaniem PDT z błękitem metylenowym. Na podstawie badania mykologicznego ustalono, że $\mathrm{u}$ analizowanych pacjentów schorzenie zostało wywołane przez grzyby z gatunku T. rubrum. Wewnątrzpłytkowa grzybica paznokci ma postać rozlanych, mlecznobiałych przebarwień w obrębie chorego paznokcia, z zachowaną prawidłową grubością i powierzchnią płytki paznokciowej, przy braku hiperkeratozy i onycholizy łożyska paznokcia. Ten typ grzybicy paznokci często wiąże się z zakażeniem gatunkami Trichophyton soudanense i Trichophyton violaceum. Autorzy wybrali jednak do badania 4 pacjentów z potwierdzoną badaniem mykologicznym obecnością T. rubrum. U uczestników zastosowano roztwór 2\% błękitu metylenowego, a następnie naświetlania lampą LED $\left(630 \mathrm{~nm}, 36 \mathrm{~J} / \mathrm{cm}^{2}\right.$, natężenie światła $3100 \mathrm{~mW} / \mathrm{cm}^{2}$, gęstość optyczna $100 \mathrm{~mW} / \mathrm{cm}^{2}$ ). Protokół powtarzano co 15 dni przez 6 miesięcy. W przypadku niektórych zmian konieczna była abrazja paznokcia z zastosowaniem frezu z obrotową końcówką diamentową $3 \mathrm{~mm}$. Wszyscy pacjenci zostali wyleczeni, co potwierdzono badaniem mykologicznym i laboratoryjnym. W pracy nie określono okresu obserwacji.

Ci sami autorzy [19] przeprowadzili badanie porównawcze, w którym 8 chorych na grzybicę paznokci podzielono na 2 grupy. W jednej grupie stosowano błękit metylenowy i PDT (MB 2\%; LED 630 nm $18 \mathrm{~J} / \mathrm{cm}^{2}$ ) oraz placebo, a w drugiej grupie flukonazol jako uzupełnienie terapii PDT. Badania kontrolne przeprowadzono po upływie 3, 6 i 12 miesięcy od leczenia. Po 12 miesiącach wyleczenie potwierdzone 
Gilaberte et al. [23] conducted a really interesting clinical trial involving 40 onychomycosis patients. This article compared the effect of three sessions of urea $40 \%$ plus MAL-PDT with placebo (urea $40 \%$ plus red light). The patients were evaluated after 36 months of follow up. Four patients in the treatment group and one patient in the control group achieved mycological and clinical cure. Although there were a small number of cured patients in the PDT group and surprisingly one patient in the placebo group was cured, the authors believe that MALPDT may constitute an alternative for onychomycosis in patients which cannot receive systemic antifungal agents.

Another trial involving a larger number of patients was conducted by Koren et al. [24]. These researchers evaluated the efficacy of $20 \%$ ALA-PDT compared to of $5 \%$ amorolfine (as a nail lacquer) after pretreatment with fractional ablative $\mathrm{CO}_{2}$ laser. According to these authors, pretreatment with ablative fractional lasers increases the permeation and absorption of topical drugs improving their efficacy. The patients involved in the trial had bilateral onychomycosis. The toenail of the right foot of the patients was then pretreated with FACL (Lumenis, UltraPulse, Yokneam, Israel, Setting: SCAARFX mode, energy: $150 \mathrm{~mJ}$, density: $3 \%$, one pass, small spot size). The first group of patients had $20 \%$-ALA applied to the toenails for 3 hours under occlusion. After that, red light was applied and kept under occlusion using an opaque shield for 3 hours. At the end of the incubation period, red light $(630 \mathrm{~nm})$ was delivered at a dose of $75 \mathrm{~J} / \mathrm{cm}^{2}$. The protocol was repeated 6 times with a three weeks' interval. The second group was treated with $5 \%$ amorolfine nail lacquer, reapplied weekly. A total of 56 patients participated of the test. The first follow up was conducted 3 months after the end of the experiment and the second after 9 months. The results demonstrated a good efficacy for all protocols tested in the three months follow up. However, only 15 to $20 \%$ of negative mycological cultures were achieved.

Morgado et al. [25] used Aluminium-phthalocyanine chloride entrapped in oil in water nano-emulsion as a photosensitizer followed by irradiation with LED $(660 \mathrm{~nm})$ to treat 20 patients with onychomycosis. The protocol was repeated every 15 days until clinical remission of the fungal infection. Four patients gave up the treatment. Twelve reached clinical cure and 8 of those achieved laboratory cure after completing the PDT sessions.

Table 1 summarizes the main points described in the manuscripts that were analysed in the present study. badaniami klinicznymi i laboratoryjnymi stwierdzono u $80 \%$ pacjentów w obu grupach.

Souza i wsp. [20] zastosowali PDT z błękitem metylenowym w leczeniu 22 pacjentów z grzybicą paznokci wywołaną przez T. rubum. W pierwszej kolejności na zajęte grzybicą paznokcie aplikowano wodny roztwór błękitu metylenowego (2\%). W niektórych przypadkach niezbędne było wykonanie dermabrazji. Następnie przeprowadzano naświetlania lampą LED $\left(600 \mathrm{~nm}, 100 \mathrm{mV} / \mathrm{cm}^{2}\right)$. Zabiegi były powtarzane co 15 dni przez 6 miesięcy. Po zakończeniu leczenia u wszystkich pacjentów stwierdzono poprawę kliniczną oraz wyleczenie potwierdzone badaniem mykologicznym.

Tardivo i wsp. [21] przeprowadzili badanie analizujące leczenie fotodynamiczne pacjentów z grzybicą paznokci z zastosowaniem mieszaniny 1 : 1 błękitu metylenowego (2\%) i błękitu toluidynowego (2\%) jako substancji o właściwościach fotouczulających. Płytkę paznokciową opracowano ostrą łyżeczką dermatologiczną, a następnie zaaplikowano mieszaninę między płytkę a łożysko paznokcia na 5 minut. Kolejnym etapem było naświetlanie obszaru objętego zmianami lampą LED (600-700 nm, $\left.100 \mathrm{~mW} / \mathrm{cm}^{2}\right)$. Leczenie zgodne $\mathrm{z}$ opisanym protokołem zastosowano u łącznie 62 pacjentów. Po 30 dniach od PDT u $45 \%$ uczestników stwierdzono pełne, a u $40 \%$ częściowe wyleczenie kliniczne.

Analizowano również skojarzenia różnych metod jako potencjalne schematy leczenia grzybicy paznokci. Oliveira i wsp. [22] badali stosowanie lasera frakcyjnego $\mathrm{CO}_{2} 10,600 \mathrm{~nm}$ i PDT z MAL (16\%) podczas jednej sesji terapeutycznej. U każdego pacjenta wykonano 2 zabiegi PDT w odstępach 60 dni. Po upływie rocznego okresu obserwacji wyleczenie potwierdzone wynikami badania mykologicznego i klinicznego stwierdzono u wszystkich 7 pacjentów. Za pomocą lasera frakcyjnego możliwe jest usunięcie obszaru objętego zakażeniem grzybiczym.

Gilaberte i wsp. [23] przeprowadzili ciekawe badanie kliniczne z udziałem 40 pacjentów z grzybicą paznokci. Porównywali skuteczność trzech zabiegów obejmujących aplikację mocznika 40\% i MAL-PDT z placebo (mocznik $40 \%$ i naświetlanie światłem czerwonym). Pacjentów poddano ocenie po 36 miesiącach obserwacji. Wyleczenie potwierdzone wynikami oceny klinicznej i badania mykologicznego stwierdzono u 4 pacjentów w grupie leczonej i 1 pacjenta w grupie kontrolnej. Choć w grupie PDT wyleczono niewielką liczbę pacjentów, a wyleczenie stwierdzono także nieoczekiwanie $u$ pacjenta $z$ grupy placebo, autorzy uważają, że MAL-PDT może stanowić alternatywną opcję leczenia grzybicy paznokci u pacjentów, którzy nie mogą przyjmować ogólnie leków przeciwgrzybiczych. 


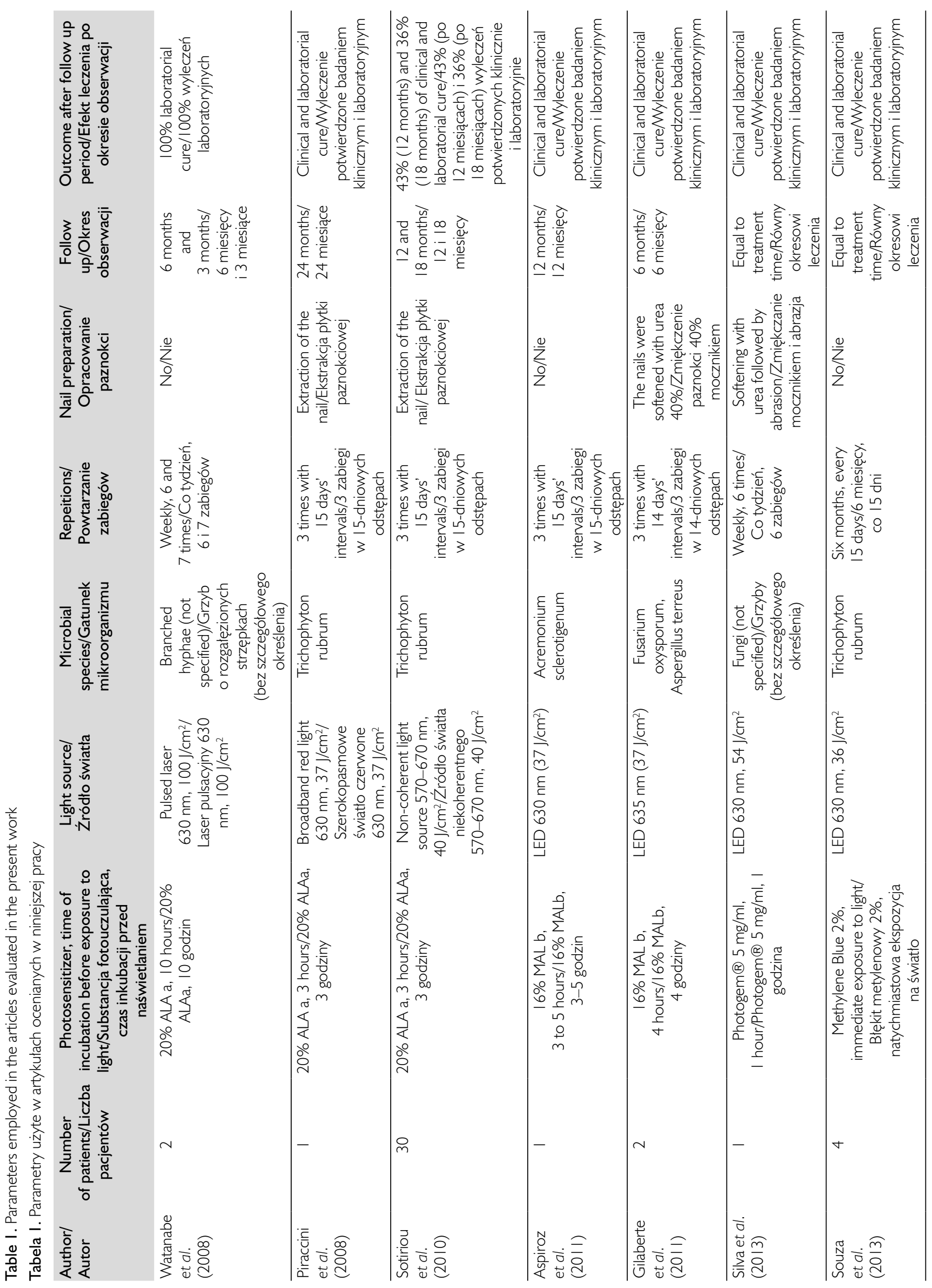




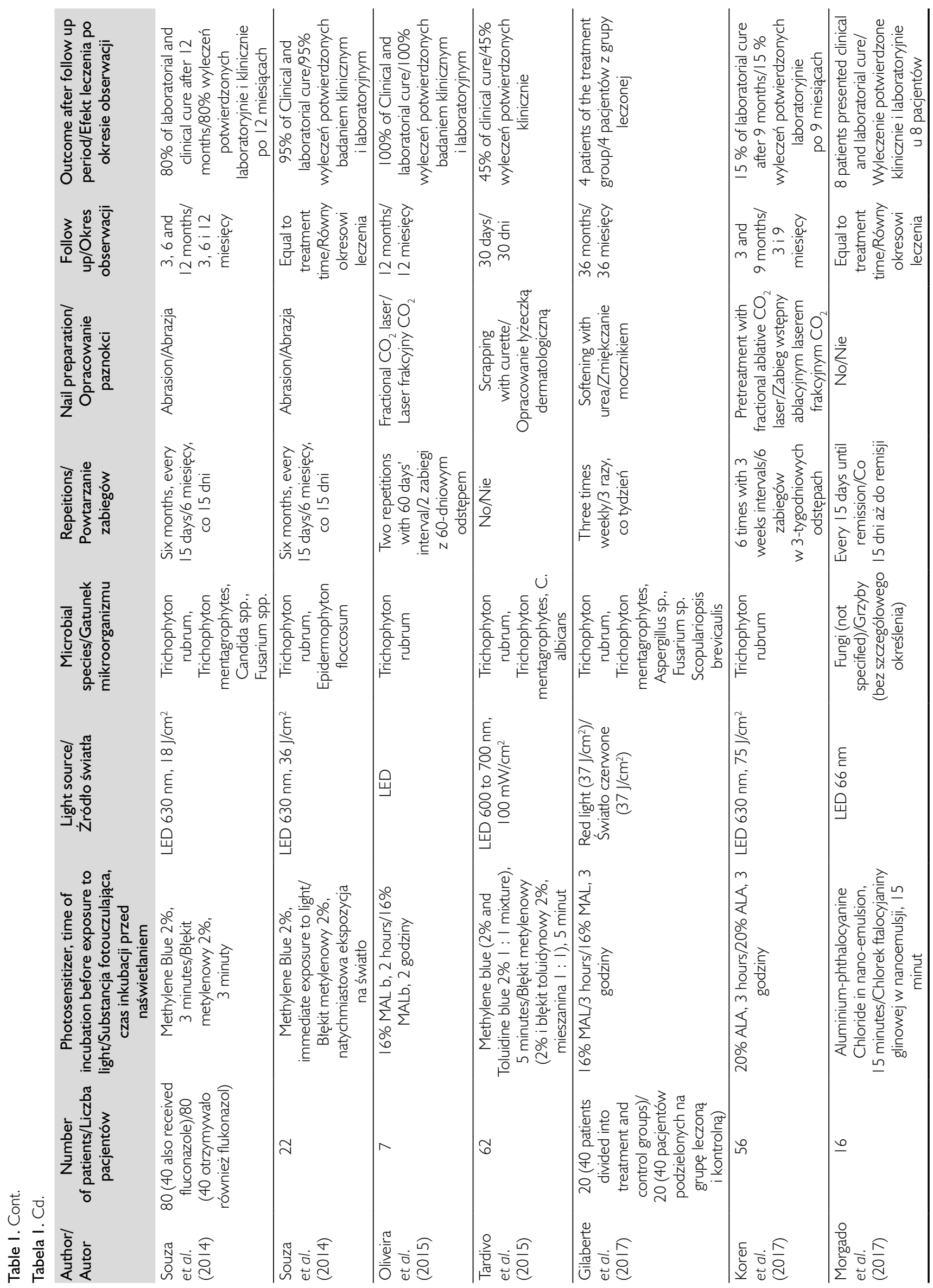




\section{DISCUSSION}

Onychomycosis had been traditionally treated with oral or topical conventional antifungal agents. According to Piraccini et al. [9], oral treatments could have the disadvantage of the potential hepatotoxicity, while topical antifungals have a limited efficacy due to the lack of penetration on the nail debridement, the combination of these two modalities often being the best alternative to the treatment of fungal nail infections. Morgado et al. [25] affirm that the long treatment protocols, which are established for topical and oral conventional antifungals, contribute to the lack of compliance of the patients. Besides, the long treatment protocols can be associated to kidney and liver failure [25]. Kreijkamp-Kaspers et al. [26] conducted a review involving several clinical trials in order to assess which was the most efficient oral antifungal treatment for onychomycosis. Azoles and terbinafine were the main antifungals utilized; terbinafine reached better cure rates than azoles with no difference in the occurrence of adverse effects. Nevertheless, it is worth noticing that these medications achieved only $31-57 \%$ clinical cure and $43-73 \%$ mycological cure in the trials evaluated by these authors. In order to consider antifungal PDT as a valuable alternative for the treatment of onychomycosis, it is necessary that the clinical practice demonstrates better or at least equal results than those achieved by the conventional oral antifungal agents with less adverse effects. On the other hand, PDT could be a valuable tool, particularly to those patients with concomitant systemic disease, for whom the oral antifungal agents would be contraindicated.

The clinical trials involving the efficacy of PDT for the treatment of onychomycosis are scarce. Only 14 manuscripts on the subject were found in PubMed in a period of ten years. Five of them were case reports about one or two patients and the protocols employed largely differed from each other. Case reports tended to have better rates of success than wider trials. The success of one or two patients should not be considered an indicative of success or failure of the technique.

Another problem is the lack of standardization of the parameters employed to assess the cure rates. Some studies use a period of 12 months or longer for the follow up, while others evaluate the lesions right after the end of the treatment. One of the greatest problems in the treatment of onychomycosis is the high rate of relapse. One of the trials [14] showed a drop in the rates of clinical and laboratorial cure from $43 \%$ at 12 months to $36 \%$ at 18 months. This could have happened in trials that achieved 100\% cure rates at the end of the treatment if they had been evaluated at 12, 18 or 24 months after that.
Kolejne badanie z udziałem większej liczby pacjentów przeprowadzili Koren i wsp. [24]. Oceniali skuteczność terapii 20\% ALA-PDT w porównaniu z 5\% amorolfiną (w postaci leczniczego lakieru do paznokci) po wstępnym leczeniu ablacyjnym laserem frakcyjnym $\mathrm{CO}_{2}$. Według autorów wstępny zabieg ablacyjnym laserem frakcyjnym zwiększa przenikanie i wchłanianie leków miejscowych, podnosząc ich skuteczność. U pacjentów uczestniczących w badaniu występowała obustronna grzybica paznokci. Paznokieć prawej stopy poddano wstępnemu zabiegowi laserem FACL (Lumenis, UltraPulse, Yokneam, Izrael; ustawienie: tryb SCAARFX; energia: 150 mJ, gęstość: $3 \%$, jedno przejście przez obszar zabiegowy, mała wielkość plamki). U pacjentów z pierwszej grupy na paznokcie stóp aplikowano 20\% ALA pod opatrunkiem okluzyjnym na 3 godziny. Następnie wykonywano naświetlanie światłem czerwonym, a na obszar objęty zabiegiem stosowano okluzję przy użyciu nieprzezroczystej osłony przez 3 godziny. Na koniec okresu inkubacji przeprowadzano zabieg światłem czerwonym $(630 \mathrm{~nm}) \mathrm{w}$ dawce $75 \mathrm{~J} / \mathrm{cm}^{2}$. Protokół powtarzano 6-krotnie w odstępie 3 tygodni. W drugiej grupie prowadzono terapię leczniczym lakierem do paznokci zawierającym $5 \%$ amorolfinę, aplikowanym raz w tygodniu. W badaniu wzięło udział łącznie 56 pacjentów. Pierwszą kontrolę przeprowadzono po 3 miesiącach, a drugą po 9 miesiącach od zakończenia badania. Wyniki uzyskane po 3 miesiącach obserwacji wykazały skuteczność wszystkich badanych protokołów leczenia, jednak w zaledwie 15-20\% przypadków uzyskano ujemny wynik posiewu mykologicznego.

Morgado i wsp. [25] zastosowali chlorek ftalocyjaniny glinowej w postaci nanoemulsji typu olej w wodzie jako fotouczulacz, a następnie przeprowadzili naświetlanie lampą LED (660 nm) w grupie 20 pacjentów z grzybicą paznokci. Protokół powtarzano co 15 dni aż do uzyskania klinicznej remisji zakażenia grzybiczego. Z leczenia zrezygnowało 4 pacjentów. U 12 uczestników badania stwierdzono wyleczenie kliniczne, z czego u 8 potwierdzono je wynikami badania laboratoryjnego po zakończeniu zabiegów PDT.

W tabeli 1 zestawiono główne dane analizowane $\mathrm{w}$ pracach objętych przeglądem.

\section{DYSKUSJA}

Grzybicę paznokci tradycyjnie leczono doustnymi lub miejscowymi lekami przeciwgrzybiczymi. Piraccini i wsp. [9] wskazują, że leczenie doustne może się wiązać z hepatotoksycznością, natomiast miejscowe środki przeciwgrzybicze mają ograniczoną skuteczność przy braku odpowiedniego opracowania płytki paznokciowej ułatwiającego wnikanie leku. Połączenie obu metod jest często najlepszą opcją w leczeniu grzybicy 
The research studies employed the following photosensitizers: porphyrins (ALA, MAL and hematoporphyrin derivative Photogem ${ }^{\circledR}$ ), phenothiazines (methylene blue and toluidine blue) and phthalocyanines (aluminium-phthalocyanine chloride). Calzavara-Pinton, Venturini and Sala [28] affirm that dermatophyte fungi are selective to porphyrins, phenothiazines, phthalocyanines, and protoporphyrin IX via aminolevulinic acid. The general mechanism of action of photosensitizers consists in the transfer of light energy allowing the generation of reactive oxygen. ALA is not a photosensitizer itself but it is converted in the photosensitizer protoporphyrin IX by the cell. MAL is the methyl ester cream of ALA, more lipophilic and deeper absorbed by skin cells.

The most common species involved in onychomycosis is T. rubrum. It is possible to notice that most of the manuscripts analysed in the present work reported the isolation of T. rubrum from the nail lesions. Besides, when more patients were involved, T. rubrum was isolated in the majority of the cases. Other fungi involved were other dermatophytes (Trichophyton mentagrophytes and Epidermophyton floccosum), Candida sp., Aspergillus sp. and Fusarium sp. In vitro studies have demonstrated the efficacy of PDT against many fungal species, including those mentioned here (it is not possible to infer if the different fungal species can influence the clinical outcome due to the small number of articles evaluated and the great diversity of methodologies employed in these studies).

Four of the studies employed ALA (20\%) as a photosensitizer. This drug is approved for use in humans and Kamp et al. [27] demonstrated that T. rubrum was able to metabolize ALA to PpIX in vitro. While Watanabe et al. [12] and Piraccini et al. [13] were $100 \%$ successful employing this dye in their case reports, Sotiriou et al. [14] reached only $36 \%$ cure when 22 patients were treated and for Koren et al. [24], only $9 \%$ of the 56 patients involved in the trial were considered cured after 9 months of follow up. It is possible to infer that, in some cases, the extraordinary high levels of cure could be correlated to a small number of patients or to short intervals of follow up.

Methyl aminolevulinate $(16 \%)$ was also employed in four studies and again, this protocol was successful with one or two patients $[15,16]$. However, when broader groups were tested by the same researchers, only four from 20 patients reached clinical and laboratorial cure after 36 months of follow up.

Other four studies tested Methylene Blue as a photosensitizer and this dye seems to promote high cure rates even in a large group of patients. Souza, Souza and Botelho reached $80 \%$ clinical and paznokci. Morgado i wsp. [25] podkreślają, że długie protokoły leczenia ustalone dla tradycyjnych miejscowych i doustnych leków przeciwgrzybiczych przyczyniają się do nieprzestrzegania zaleceń przez pacjentów. Ponadto długotrwałe leczenie może się wiązać z ryzykiem rozwoju niewydolności nerek i wątroby [25]. Kreijkamp-Kaspers i wsp. [26] przeprowadzili przegląd kilku badań klinicznych, aby określić najskuteczniejszy schemat doustnego leczenia przeciwgrzybiczego u osób z grzybicą paznokci. Głównymi stosowanymi środkami przeciwgrzybiczymi były leki z grupy azoli i terbinafina. Terbinafina odznaczała się lepszymi wskaźnikami wyleczenia niż leki azolowe, nie odnotowano natomiast różnic w występowaniu działań niepożądanych. Warto jednak zwrócić uwagę, że w badaniach analizowanych przez autorów przeglądu wskaźniki wyleczeń potwierdzonych klinicznie i mykologicznie wyniosły zaledwie odpowiednio $31-57 \%$ oraz $43-73 \%$. Aby można było uznać PDT za wartościową alternatywę w leczeniu grzybicy paznokci, należy wykazać w praktyce klinicznej, że umożliwia uzyskiwanie co najmniej takich samych efektów terapeutycznych jak tradycyjne doustne leki przeciwgrzybicze, wywołując przy tym mniej działań niepożądanych. Jednocześnie PDT może być przydatną opcją terapeutyczną zwłaszcza u pacjentów obciążonych współistniejącą chorobą układową, u których stosowanie doustnych leków przeciwgrzybiczych mogłoby być przeciwwskazane.

Przeprowadzono niewiele badań klinicznych analizujących skuteczność PDT w leczeniu grzybicy paznokci. $W$ bazie danych PubMed wyszukano zaledwie 14 prac o tej tematyce, obejmujących okres 10 lat. Wśród nich znalazło się 5 opisów przypadków dotyczących 1-2 pacjentów, a zastosowane protokoły leczenia znacząco różniły się od siebie. W opisach przypadków wskaźniki skuteczności terapeutycznej są zazwyczaj wyższe niż w szerzej zakrojonych badaniach. Pomyślne wyniki leczenia uzyskane u kilku pacjentów nie stanowią definitywnego potwierdzenia skuteczności ani braku skuteczności metody.

Kolejnym problemem jest brak standaryzacji parametrów stosowanych w ocenie efektów leczenia. W niektórych badaniach okres obserwacji wynosił 12 miesięcy lub dłużej, natomiast w innych ocenę przeprowadzano bezpośrednio po zakończeniu leczenia. Do głównych problemów w terapii grzybicy paznokci należy wysoki wskaźnik nawrotów. W jednym z badań [14] zaobserwowano spadek wskaźnika wyleczeń potwierdzonych klinicznie i laboratoryjnie z $43 \%$ po 12 miesiącach od zakończenia leczenia do $36 \%$ po 18 miesiącach. Istnieje możliwość, że taki spadek mógłby nastąpić również w badaniach, w których po zakończeniu terapii uzyskano 100\% wyleczeń, gdyby pacjenci byli poddawani kolejnym ocenom po upływie 12, 18 czy 24 miesięcy. 
Photodynamic therapy (PDT) is a technique involving the production of reactive oxygen species through a photosensitizer and light of a specific wavelength

Terapia fotodynamiczna (PDT) polega na wytwarzaniu reaktywnych form tlenu poprzez stosowanie substancji fotouczulającej i światła o określonej długości fali

It has been suggested that PDT could be an alternative to antifungal conventional treatment

Sugeruje się, że PDT może być alternatywą dla tradycyjnego leczenia przeciwgrzybiczego

What do we know about in vivo employment of PDT against onychomycosis so far?

Co wiemy o skuteczności PDT in vivo w leczeniu grzybicy paznokci?

PubMed search $\rightarrow$ Photodynamic Therapy; Onychomycosis
Wyszukiwanie w bazie PubMed $\rightarrow$ terapia fotodynamiczna;
grzybica paznokci
The manuscript retrieved manuscripts were analysed. Protocols
differ considerably.
in order to improve the researches
standardized parameters
Wyszukane prace poddano analizie. Stwierdzono znaczące
różnice między protokołami leczenia. Wyniki leczenia są ogólnie
dobre, ale aby zwiększyć miarodajność badań, konieczne jest
przyjęcie ujednoliconych parametrów

Figure I. Photodynamic therapy

Rycina I. Terapia fotodynamiczna

laboratorial cure in 80 patients after a 36 months' period of follow up, regardless of the concomitant use of fluconazole in half of the patients. On the other hand, Tardivo et al. [21] reached $45 \%$ cure in 62 patients, which is also an acceptable rate of success. Although Souza et al. [20] found no statistically significant difference between the group of patients that received PDT and Fluconazole, this alternative protocol could be more explored in the future in vivo trials. The synergism between PDT and conventional antifungal treatments has been already demonstrated in vitro [3].

The majority of the studies needed some kind of abrasion or softening of the nail in order to enhance the penetration of the dye in the affected area. Some studies involved the softening with urea and even clipping the nail off, others use $\mathrm{CO}_{2}$ laser or removal of nail thickness with a curate or a drill.
Badacze stosowali następujące substancje fotouczulające: porfiryny (ALA, MAL i pochodną hematoporfiryny Photogem ${ }^{\circledR}$ ), fenotiazyny (błękit metylenowy i błękit toluidynowy) oraz ftalocyjaniny (chlorek ftalocyjaniny glinowej). Calzavara-Pinton, Venturini i Sala [28] potwierdzili, że grzyby dermatofitowe są selektywnie podatne na porfiryny, fenotiazyny, ftalocyjaniny i protoporfirynę IX - po przekształceniu z kwasu aminolewulinowego. Ogólny mechanizm działania substancji fotouczulających polega na aktywacji reaktywnych form tlenu przy wykorzystaniu energii świetlnej. ALA nie ma właściwości fotouczulających, ale jest przekształcany w substancję fotouczulającą (protoporfirynę IX) w komórce. MAL jest estrem metylowym ALA w postaci kremu. Ma bardziej lipofilny charakter i głębiej wnika w komórki skóry.

Najczęstszym gatunkiem grzyba wywołującym grzybicę paznokci jest T. rubrum. Należy zauważyć, że T. rubrum izolowano ze zmian w obrębie paznokci w większości prac analizowanych w niniejszym przeglądzie. Ponadto w badaniach z większą liczbą uczestników gatunek T. rubrum był izolowany w większości przypadków. Wśród innych grzybów stwierdzano obecność innych dermatofitów (Trichophyton mentagrophytes i Epidermophyton floccosum) oraz gatunki z rodzajów Candida, Aspergillus i Fusarium. Badania in vitro wykazały skuteczność PDT w zwalczaniu licznych gatunków grzybów, także wymienionych powyżej (nie można stwierdzić, czy obecność określonych gatunków grzybów może wpływać na efekt kliniczny leczenia ze względu na niewielką liczbę analizowanych artykułów i dużą różnorodność metodologii stosowanych w przeprowadzonych badaniach).

W czterech badaniach wykorzystywano ALA (20\%) jako substancję fotouczulającą. Lek jest zatwierdzony do stosowania u ludzi, a Kamp i wsp. [27] w swoim badaniu wykazali, że T. rubrum ma zdolność metabolizowania ALA do PpIX in vitro. Choć Watanabe i wsp. [12], a także Piraccini, i wsp. [13] w swoich opisach przypadków stwierdzili 100-procentową skuteczność tego barwnika, Sotiriou i wsp. [14] odnotowali zaledwie $36 \%$ wyleczeń w analizowanej grupie liczącej 22 osoby, a Koren i wsp. [24] zaledwie 9\% w grupie 56 uczestników badania uznali za wyleczonych po 9 miesiącach obserwacji. Nasuwa się wniosek, że w niektórych przypadkach bardzo wysokie wskaźniki wyleczeń mogą wynikać z niewielkiej liczby pacjentów lub krótkich odstępów pomiędzy badaniami kontrolnymi.

W czterech innych badaniach autorzy stosowali MAL (16\%) jako fotouczulacz, a protokół okazał się skuteczny u 1-2 pacjentów $[15,16]$. W badaniu liczniejszych grup przeprowadzonym przez tych samych autorów wyleczenie kliniczne i laboratoryjne po 36 miesiącach obserwacji uzyskano jednak u zaledwie 4 spośród 20 pacjentów.

W czterech innych badaniach analizowano błękit metylenowy jako substancję fotouczulającą. Na podsta- 


\section{CONCLUSIONS}

Considering the relatively good results achieved by in vivo studies, PDT could be studied as a suitable alternative for the treatment of onychomycosis, especially for patients that cannot be have conventional therapies and for those that have tried them with no results. There is still no consensus on the best protocol to be applied and if we analyse different protocols, there are very few studies on the subject and even fewer involving a larger number of patients. Some parameters, such as the photosensitizer, the light dose and light source, pre-treatment of the affected nail, time of follow up need to be more consistently established. For this reason, trials should be performed to compare the different parameters that have been frequently used. A more standardized approach would benefit from the possible widespread use of this promising technique in the clinical management of onychomycosis.

\section{CONFLICT OF INTEREST}

The authors declare no conflict of interest. wie otrzymanych wyników wydaje się, że barwnik ten pozwala uzyskać wysokie wskaźniki wyleczenia także w dużej grupie pacjentów. Souza, Souza i Botelho odnotowali wskaźnik wyleczeń rzędu $80 \%$ (na podstawie wyników badania klinicznego i laboratoryjnego) u 80 pacjentów po 36 miesiącach obserwacji, niezależnie od jednoczesnego stosowania flukonazolu u połowy uczestników badania. Natomiast w badaniu Tardivo i wsp. [21] odsetek wyleczeń w grupie 62 pacjentów wyniósł $45 \%$, co również stanowi akceptowalny wskaźnik skuteczności leczenia. Mimo że Souza i wsp. [20] nie stwierdzili statystycznie istotnej różnicy między grupa pacjentów leczonych PDT i flukonazolem, zasadne byłoby przeanalizowanie tego alternatywnego protokołu leczenia w przyszłych badaniach in vivo. Synergistyczne działanie PDT i konwencjonalnych metod leczenia przeciwgrzybiczego wykazano już w warunkach in vitro [3].

W większości badań konieczne było opracowanie (abrazja) lub zmiękczenie paznokcia, aby zwiększyć penetrację barwnika w obszar objęty zmianami. W niektórych badaniach paznokcie zmiękczano za pomocą mocznika lub usuwano płytkę paznokciową. W innych stosowano laser $\mathrm{CO}_{2}$ lub redukowano grubość paznokcia za pomocą łyżeczki dermatologicznej lub frezu.

\section{WNIOSKI}

Z uwagi na stosunkowo dobre wyniki uzyskane $\mathrm{w}$ badaniach in vivo uzasadnione jest badanie PDT jako wartościowej opcji w leczeniu grzybicy paznokci, szczególnie u pacjentów, którzy nie mogą stosować tradycyjnego leczenia lub u których tradycyjna terapia nie przynosi efektu. Nadal nie ma zgodności co do optymalnego protokołu leczenia, a analizę różnych protokołów utrudnia fakt, że dostępna jest bardzo niewielka liczba badań o tej tematyce, przy czym jeszcze mniej jest badań prowadzonych w większych grupach pacjentów. Niektóre parametry, takie jak substancja uczulająca, dawka naświetlania i źródło światła, wstępne opracowanie zajętego zmianami grzybiczymi paznokcia i czas obserwacji, wymagają większego ujednolicenia. $Z$ tego względu niezbędne jest przeprowadzenie badań porównujących często stosowane parametry. Bardziej ujednolicone podejście mogłoby przynieść korzyści pod względem rozpowszechnienia tej obiecującej metody $\mathrm{w}$ postępowaniu klinicznym u pacjentów z grzybicą paznokci.

\section{KONFLIKT INTERESÓW}

Autorzy nie zgłaszają konfliktu interesów. 
References

Piśmiennictwo

1. Moreira L.M., Santos F.V., Lyon J.P., Maftoum-Costa M., Pacheco-Soares C., Soares da Silva N.: Photodynamic therapy: phorphyrins and phthalocyanines as photosenssitzers. Austr J Chem 2008, 61, 741-754.

2. Kharkwal G.B., Sharma S.K., Huang Y.Y., Dai T., Hamblin M.R.: Photodynamic therapy for infections: clinical applications. Lasers Surg Med 2011, 43, 755-767.

3. Lyon J.P., Carvalho C.R., Rezende R.R., Lima C.J., Santos F.V., Moreira L.M.: Synergism between fluconazole and methylene blue photodynamic therapy against fluconazole resistant Candida strains. Indian J Med Microbiol 2016, 34, 506-508.

4. Lyon J.P., Moreira L.M., Moraes P.C.G., Santos F.V., Resende M.A.: Photodynamic therapy for patogenic fungi. Mycoses 2011, 54, 265-271.

5. Baltazar L.M., Ray A., Santos D.A., Cisalpino P.S., Friedman A.J., Nosanchuk J.D.: Antimicrobial photodynamic therapy: an effective alternative approach to control fungal infections. Front Microbiol 2015, 13, 1-11.

6. Lyon J.P., Azevedo C.M.P.S., Moreira L.M., Lima C.J., Resende M.A.: Photodynamic therapy against chromoblastomycosis. Mycopathol 2011, 172, 293-297.

7. Calzavara-Pinton P., Rossi M.T., Sala R., Venturini M.: Photodynamic antifungal chemotherapy. Photochem Photobiol 2012, $88,512-522$

8. Asz-Sigall D., Tosti A., Arenas R.: Tinea unguium: diagnosis and treatment in practice. Mycopathol 2017, 182, 95-100.

9. Gupta A.K., Stec N., Summerbell R.C., Shear N.H., Piguet V., Tosti A., Piraccini B.M.: Onychomycosis: a review. J Eur Acad Dermatol Venereol 2020, 34, 1972-1990.

10. Gupta A.K., Simpson F.C.: New therapeutic options for onychomycosis. Expert Opin Pharmacother 2012, 13, 1131-1142.

11. Moher D., Liberati A., Tetzlaff J., Altman D.G.: Preferred reporting items for systematic reviews and meta-analyses: the PRISMA statement. PloS Med 2009, 21, 6e1000097.

12. Watanabe D., Kawamura C., Masuda Y., Akita Y., Tamada Y., Matsumoto Y.: Successful treatment of toenail onychomycosis with photodynamic therapy. Arch Dermatol 2008, 144, 19-21.

13. Piraccini B.M., Rech G., Tosti A.: Photodynamic therapy of onychomycosis caused by Trichophyton rubrum. J Am Acad Dermatol 2008, 59, S75-76.

14. Sotiriou E., Koussidou-Eremonti T., Chaidemenos G., Apalla Z., Ioannides D.: Photodynamic therapy for distal and lateral subungual toenail onychomycosis caused by Trichophyton rubrum: preliminary results of a single-centre open trial. Acta Derm Venereol 2010, 90, 216-217.

15. Aspiroz C., Fortuño Cebamanos B., Rezusta A., Paz-Cristóbal P., Domínguez-Luzón F., Gené Díaz J., et al.: Photodynamic therapy for onychomycosis: case report and review of the literature. Rev Iberoam Micol 2011, 28, 191-193.

16. Gilaberte Y., Aspiroz C., Martes M.P., Alcalde V., Espinel-Ingroff A., Rezusta A.: Treatment of refractory fingernail onychomycosis caused by nondermatophyte molds with methylaminolevulinate photodynamic therapy. J Am Acad Dermatol 2011, 65, 669-671.

17. Silva A.P., Kurachi C., Bagnato V.S., Inada N.M.: Fast elimination of onychomycosis by hematoporphyrin derivative-photodynamic therapy. Photodiagnosis Photodyn Ther 2013, 10, 328-330.

18. Souza L.W., Souza S.V., Botelho A.C.: Endonyx toenail onychomycosis caused by Trichophyton rubrum: treatment with photodynamic therapy based on methylene blue dye. An Bras Dermatol 2013, 88, 1019-1021.

19. Figueiredo Souza L.W., Souza S.V., Botelho A.C.: Randomized controlled trial comparing photodynamic therapy based on methylene blue dye and fluconazole for toenail onychomycosis. Dermatol Ther 2014, 27, 43-47.

20. Souza L.W., Souza S.V., Botelho A.C.: Distal and lateral toenail onychomycosis caused by Trichophyton rubrum: treatment with photodynamic therapy based on methylene blue dye. An Bras Dermatol 2014, 89, 184-186.

21. Tardivo J.P., Wainwright M., Baptista M.: Small scale trial of photodynamic treatmet of onychomycosis in São Paulo. J Photochem Photobiol B 2015, 150, 66-68.

22. de Oliveira G.B., Antonio J.R., Antonio C.R., Tomé F.A.: The association of fractional CO2 laser $10.600 \mathrm{~nm}$ and photodynamic therapy in the treatment of onychomycosis. An Bras Dermatol 2015, 90, 468-471.

23. Gilaberte Y., Robres M.P., Frías M.P., García-Doval I., Rezusta A., Aspiroz C.: Methyl aminolevulinate photodynamic therapy for onychomycosis: a multicentre, randomized, controlled clinical trial. J Eur Acad Dermatol Venereol 2017, 31, 347-354.

24. Koren A., Salameh F., Sprecher E., Artzi O.: Laser-assisted photodynamic therapy or laser-assisted amorolfine lacquer delivery for treatment of toenail onychomycosis: an open-label comparative study. Acta Derm Venereol 2018, 98, 467-468.

25. Morgado L.F., Trávolo A.R.F., Muehlmann L.A., Narcizo P.S., Nunes R.B., Pereira P.A.G., et al.: Photodynamic therapy treatment of onychomycosis with aluminium-phthalocyanine chloride nanoemulsions: a proof of concept clinical trial. J Photochem Photobiol B 2017, 173, 266-270.

26. Kreijkamp-Kaspers S., Hawkw K.L., Driel M.L.: Oral medication to treat toenail fungal infections. JAMA 2018, 23, 319: 397-398.

27. Kamp H., Tietz H.J., Lutz M., Piazena H., Sowyrda P., Lademann J., et al.: Antifungal effect of 5-aminolevulinic acid PDT in Trichophyton rubrum. Mycoses 2005, 48, 101-107.

28. Calzavara-Pinton P.G., Venturini M., Sala R.: A comprehensive overview of photodynamic therapy in the treatment of superficial fungal infections of the skin. J Photochem Photobiol B 2005, 78, 1-6.

Received: 26.08 .2020

Accepted: 7.09 .2020

Otrzymano: $26.08 .2020 \mathrm{r}$

Zaakceptowano: $7.09 .2020 \mathrm{r}$.

How to cite this article

Lyon J.P., Moreira L.M.: Photodynamic therapy against onychomycosis - an overview about the in vivo application.

Dermatol Rev/Przegl Dermatol 2020, 107, 521-533. DOI: https://doi.org/10.5114/dr.2020.103888 